\title{
TINDAK TUTUR ILOKUSI ANTARA GURU DAN SISWA PADA ANAK PENYANDANG DOWN SYNDROME
}

\author{
Inten Fitriani \\ Liliana Muliastuti \\ Asisda WAP
}

\begin{abstract}
Abstrak. Penelitian ini membahas mengenai fenomena tindak tutur yang dimiliki para siswa penyandang $D S$ pada SLB Dharma Wanita Bogor. Penelitian dilaksanakan dengan menggunakan metode deskriptif kualitatif melalui analisis percakapan antara guru dan siswa dengan merekam aktivitas belajar mengajar di SLB Dharma Wanita Kota Bogor di dalam kelas. Pada analisis tindak tutur ilokusi para siswa SLB Dharma Wanita Kota Bogor ditemukan ilokusi asertif 25 buah, ilokusi direktif 7 buah, ilokusi komisif 5 buah, ilokusi ekspresif 4 buah, ilokusi deklaratif tidak ditemukan. Penelitian ini menyimpulkan bahwa jenis tindak tutur para siswa pada anak penyandang $D S$ di SLB Dharma Wanita Kota Bogor yang paling banyak ditemukan ialah ilokusi asertif, yaitu sebanyak 25 buah. Ilokusi asertif menjadi jenis tindak tutur yang paling sering digunakan untuk menyatakan sesuatu kepada lawan tutur karena banyaknya pernyataan yang diucapkan siswa penyandang DS.Ilokusi deklaratif jarang sekali ditemukan karena dalam percakapan antara guru dan siswa pada anak penyandang $D S$ karena tidak adanya korespondensi antara isi dan realitas.
\end{abstract}

Kata kunci: Pragmatik, Tindak Tutur, Down Syndrome

\section{PENDAHULUAN}

Bahasa merupakan suatu kebutuhan dalam kehidupan manusia. Dengan kata lain, bahasa adalah sebagai alat komunikasi yang sangat berperan dalam kemajuan pola pikir manusia. Dalam kajian ilmu bahasa terdapat salah satu ilmu yang sangat akrab dalam kehidupan manusia yaitu pragmatik yang merupakan telaah mengenai relasi antara bahasa dengan konteks yang merupakan dasar bagi suatu catatan atau laporan pemahaman bahasa. Dengan kata lain, Leech Geofrey menyatakan pragmatik adalah telaah mengenai kemampuan pemakai bahasa menghubungkan serta menyerasikan kalimat-kalimat dan konteks-konteks secara tepat. Leech menyatakan bahwa pragmatik adalah ilmu yang mengkaji bagaimana bahasa digunakan dalam komunikasi (Leech Geofrey, 1993: 1).

Berdasarkan landasan di atas, dapat ditegaskan bahwa pragmatik adalah cabang ilmu bahasa yang mempelajari struktur bahasa secara eksternal, yaitu berkaitan dengan bagaimana suatu bahasa itu digunakan dalam komunikasi.Pragmatik pada dasarnya menyelidiki bagaimana makna dibalik tuturan yang terikat pada konteks yang melingkupinya diluar bahasa, sehingga dasar dari pemahaman terhadap pragmatik adalah hubungan antara bahasa dengan konteks.

Berbicara dengan tindak tutur yang merupakan pembahasan dari pragmatik maka kita akan menengok pada sebuah studi bahasa. Kajian yang termasuk ilmu antardisipliner, yaitu neurolingusitik.Dikatakan antardisipliner adalah karena kajian ini merupakan gabungan dari dua macam ilmu, yaitu neurologi dan linguistik.Salah satu kajian dalam 
neurolinguistik adalah gangguan berbahasa dan keterlambatan berbahasa seseorang karena adanya kerusakan pada otak.

Pada mulanya neurolinguistik mewujudkan dirinya dari penemuan-penemuan afasiologi.Paul Borca dan Wernicke merupakan bapak neurolinguistik pada pertengahan abad ke-19.Teori neurolinguistik inilah satu-satunya teori yang masih bertahan dan banyak dirujuk terutama setelah diperluas oleh Lichtheim pada akhir abad ke-19 dan kemudian oleh N.Geschwind pada abad pertengahan ke-20 ini.

Tujuan utama neurolinguistik ialah untuk mengetahui bagaimana bahasa disimpan dan diproses di dalam otak dari awal pemerolehan bahasa sampai bahasa itu berkembang dalam kehidupan manusia. Dengan kata lain, neurolinguistik ingin mengetahui bagaimana otak mengatur pada waktu mengelola aspek-aspek kemampuan (competence) dan perlakuan (performance) bahasa yang begitu rumit. Dengan demikian, neurolinguistik merupakan cabang ilmu baru, baik dalam kajian neurolinguistik maupun dalam kajian neurologinya.

Kemampuan bicara merupakan alat utama untuk berkomunikasi bagi kita sebagai manusia. Ketika salah satu dari instrumen atau organ bicara terganggu, maka komunikasi seseorang akan terganggu pula. Gangguan bicara bisa terjadi pada semua orang baik dewasa maupun anak-anak.Gangguan bicara merupakan masalah dalam produksi bahasa yang dapat diketahui dengan jelas.Gangguan bicara merupakan pengubahan karakteristik atau perilaku khusus yang merintangi produksi verbal.Gangguan bicara dan bahasa meliputi sejumlah masalah berbicara, seperti gangguan artikulasi, gangguan suara, dan gangguan kefasihan.

Galih A Veskarisyanti dalam bukunya12 Terapi Autis Paling Efektif dan Hemat menjelaskan gangguan bicara pada anak-anak seringkali dialami oleh anak-anak yang mengalami retardasi mental. Retardasi mental adalah suatu keadaan perkembangan jiwa yang terhenti atau tidak lengkap, yang terutama ditandai oleh terjadinya keterampulan selama masa perkembangan sehingga berpengaruh pada tingkat kecerdasan secara menyeluruh misalnya kemampuan kognitif, motorik, bahasa, dan sosial (Galih A Veskarisyanti, 2008: 27).

Dalam ilmu neurolinguistik $D S$ seringkali mengalami keterbelakangan kemampuan motorik, seperti terlambat berbahasa dan kemampuan menghasilkan bahasa berbeda dengan anak normal yang lain.

Penyandang $D S$ adalah suatu kondisi keterbelakangan fisik dan mental anak yang diakibatkan adanya abnormalitas perkembangan kromosom.Kromosom ini terbentuk akibat kegagalan sepasang kromosom untuk saling memisahkan diri saat terjadi pembelahan.Kromosom merupakan serat-serat khusus yang terdapat di dalam setiap sel di dalam badan manusia dimana terdapat bahan-bagan genetik yang menentukan sifat-sifat seseorang. $D S$ adalah ketidakmampuan yang ditandai dengan keterbatasan yang signifikan baik dari fungsi intelektual dan prilaku adaptif seperti yang diungkapkan dalam keterampilan adaptif konseptual, sosial, dan praktis.

Penyandang $D S$ memiliki kelainan kromosom yang paling lazim dan juga merupakan penyebab ketidakmampuan intelektual yang paling sering ditemukan. $D S$ muncul bila terdapat kelebihan sebuah kromosom nomor 21.Kromosom tambahan ini, karena gen-gen yang terkandung di dalamnya menyebabkan protein-protein tertentu terbentuk secara berlebihan di dalam sel. Hal ini mengganggu pertumbuhan normal di dalam tubuh janin.Disamping itu, migrasi sel-sel yang terjadi pada pembentukan berbagai 
bagian tubuh tertentu menjadi terganggu, khususnya pada otak. Sehingga begitu individu dengan sindroma down lahir, seluruh perbedaan-perbedaan ini sudah ada karena memiliki lebih sedikit sel-sel otak dan mempunyai kelainan pembentukan otak, akan lambat belajar.

Kemampuan motorik yang tertunda antara anak $D S$ dan anak normal yang dapat dilihat dari usianya.Bahasa merupakan hal penting yang harus diajarkan sedari dini dan kemampuan berbahasa karena adanya keterlambatan pada anak penyandang $D S$ ini menjadi ketertarikan untuk melakukan penelitian ini karena adanya perbedaaan perkembangan motorik dengan anak normal lainnya.

Perkembangan motorik yaitu perkembangan pengendalian gerakan tubuh melalui kegiatan yang terkoordinir antara saraf dan otak.Perkembangan motorik meliputi motorik kasar dan halus. Dalam hal ini banyak hal yang akan kita temukan untuk melihat bentukbentuk tanggapan anak penyandang $D S$.

Fenomena tindak tutur anak penyandang $D S$ ini agar kita dapat menemukan cara yang tepat untuk memberikan pengajaran berbahasa yang baik dan tanggapan yang tepat untuk anak penyandang $D S$. Pada dasarnya anak penyandang $D S$ jangan dibedakan dengan anak normal lainnya hanya saja cara mengnanganinya harus penuh kesabaran dan kasih sayang agar memberikan rasa nyaman.

\section{METODOLOGI}

Metode penelitian yang digunakan dalam penelitian ini adalah deskriptif kualitatif untuk mengetahui tindak tutur ilokusi antara guru dan siswa anak penyandang $D S$ serta berkaitan dengan pemahaman bahasa yang diterimanya. Fokus penelitian ini adalah tindak tutur ilokusi yang terjadi antara guru dan siswa penyandang $D S$ berdasarkan bentukbentuk tanggapan yang terjadi selama pembelajaran di kelas.Penelitian ini difokuskan pada tindak tutur antara guru dan siswa anak penyandang $D S$ dengan pemahaman bahasa yang diterimanya.

\section{HASIL DAN PEMBAHASAN}

Tabel deskriptif hasil analisis guru dan siswa anak penyandang $D S$.

\begin{tabular}{lll}
\hline Tindak Tutur & Jenis & Jumlah \\
\hline \multirow{3}{*}{ Ilokusi } & Asertif & 25 \\
& Direktif & 7 \\
& Komisif & 5 \\
& Ekspresif & 4 \\
& Deklaratif & 0 \\
\hline
\end{tabular}

Berdasarkan tabel deskriptif diatas, ditentukan jenis-jenis berikut ini akan dijelaskan lebih rinci mengenai jenis-jenis tindak tutur ilokusi yang ditemukan dalam percakapan antara guru dan siswa penyandang $D S$ di SLB Dharma Wanita Kota Bogor. Tindak ilokusi yang terdiri dari jenis ilokusi asertif sebanyak 25 tuturan, ilokusi direktif sebanyak 6 tuturan, ilokusi komisif sebanyak 5 tuturan, ilokusi ekspresif sebanyak 4 tuturan, dan deklaratif sebanyak 0 tuturan. 
Arkhais, Vol. 07 No. 2 Jufi - Desember 2016

\section{Ilokusi Asertif}

Asertif yaitu ilokusi yang melibatkan pembicara pada kebenaran yang diekspresikan atau diungkapkan, seperti menyatakan(mengemukakan, mengutarakan, menyampaikan, menjelaskan,menerangkan,mengatakan), memberitahukan,menyarankan, membanggakan, mengeluh, menuntut, melaporkan. Dalam penelitian ini ditemukan ilokusi asertif berupa menyatakan, memberitahukan, dan mengeluh. Untuk kejelasan informasi mengenai data tersebut, berikut disajikan beberapa contoh:

Guru: Eh, bisa mati, terus apa lagi?

Siswa: Bisa kesamber petir

Guru: Baca, Ko

Siswa: Vivi menyalakan tivi, Vivi menyakan tivi

Guru: Warnanya ituin tuh

Siswa: Gamau ah aku capek

Ketiga kalimat ilokusi asertif di atas mengandung maksud memberitahukan dan mengeluh. Kalimat tersebut agar lawan tutur mengetahui kebenaran yang diungkapkan.

\section{Ilokusi Direktif}

Direktif yaitu ilokusi yang digunakan penutur dengan maksud untuk menimbulkan beberapa efek tindakan pada lawan tutur seperti memesan, memerintahkan, mengarahkan, memohon, meminta, melarang, menyarankan, menganjurkan, menasihati, mengusulkan, menyetujui.Dalam penelitian ini ditemukan ilokusi direktif berupa memerintahkan dan memohon. Berikut disajikan beberapa contoh:

Guru: Oh, mau sama ibu duduknya?

Siswa: Ayo nulis lagi, dikit lagi ya pinter kan.

Guru: :Nadhifah mau ke depan ga?

Siswa: Pengen titik-titik bu, pengen titik-titik

Ketiga kalimat ilokusi direktif ini mengandung maksud meminta, memerintahkan, dan memohon kepada lawan tutur.

\section{Ilokusi Komisif}

Komisif yaitu ilokusi yang digunakan penutur untuk melibatkan lawan tutur pada beberapa tindakan yang akan datang, seperti berjanji, bersumpah, mengancam, menolak, menampik, menawarkan. Berdasarkan data yang ditemukan dalam penelitian ini ditemukan ilokusi komisif berupa menawarkan dan berjanji.Untuk kejelasan ini ditemukan ilokusi komisif berjanji.

Guru: Besok? Yeee... Matematika kan sekarang, gak dibawa?

Siswa: Besok ya besok aku bawa

Guru: Yah.. Gak dibawa?

Siswa: Besok dibawa yaaa 
Kalimat ilokusi komisif di atas mengandung maksud berjanji untuk membawa apa yang diperintahkan lawan tutur pada esok hari karena hari ini tidak membawanya.

\section{Ilokusi Ekspresif}

Ilokusi ekspresif yaitu ilokusi yang mempunyai fungsi untuk mengekspresikan, mengungkapkan, atau memberitahukan sikap psikologis penutur menuju suatu pernyataan yang diperkirakan oleh kalimat penutur, seperti mengucapkan terima kasih, mengucapkan selamat, meminta maaf, memuji, menyatakan belasungkawa, menyatakan simpati, dan sebagainya. Berdasarkan data, ditemukan bentuk ilokusi ekspresif mengucapkan terima kasih, meminta maaf

Guru: Kenapa dihapus?

Siswa: Maaf ya bu

Guru: Nanti diisi ya, Vi. Jangan salah.

Siswa: Iyaaa, baik, Bu, nanti ya.

Ketiga kalimat ilokusi ekspresif di atas mengandung maksud meminta maaf dan mengucapkan terima kasih kepada lawan tutur.

\section{Ilokusi Deklaratif}

Deklaratif yaitu ilokusi yang bila perfomasinya berhasil akan menyebabkan korespondensi yang baik antara isi dengan realitas, seperti menyerahkan diri, memecat, membebaskan, membaptis, memberitakan, menamai, mengucilkan, mengangkat, menunjuk, menentukan, memvonis, dan lain sebagainya. Berdasarkan data yang diperoleh, tidak ditemukan ilokusi deklaratif pada tuturan tersebut.

Dari hasil tersebut ditemukan ilokusi yang paling banyak digunakan dalam percakapan antara guru dan siswa pada anak penyandang $D S$ ialah ilokusi asertif dan ilokusi yang paling sedikit digunakan ialah ilokusi deklaratif.

Dari 41 tuturan percakapan guru dan siswa pada anak penyandang $D S$, ditemukan jenis-jenis ilokusi. Tindak ilokusi yang terdiri dari jenis ilokusi asertif sebanyak 25 tuturan, ilokusi direktif sebanyak 7 tuturan, ilokusi komisif sebanyak 5 tuturan, ilokusi ekspresif sebanyak 4 tuturan, dan deklaratif sebanyak 0 tuturan.

Dalam data yang ditemukan, ilokusi deklaratif jarang sekali ditemukan karena dalam percakapan antara guru dan siswa pada anak penyandang $D S$ dengan maksud seperti menyerahkan diri, memecat, membebaskan, membaptis, memberitakan, menamai, mengucilkan, mengangkat, menunjuk, menentukan, memvonis, dan lain sebagainya. Disamping itu, tidak adanya korespondensi antara isi dan realitas.

\section{KESIMPULAN}

Berdasarkan hasil analisis data penelitian, penggunaan tindak tutur dalam percakapan antara guru dan siswa pada anak penyandang $D S$ berupa tindak tutur ilokusi dalam percakapan guru dan sisiwa pada anak penyandang $D S$ ditemukan 25 ilokusi asertif, 7 ilokusi direktif, 5 ilokusi komisif, 4 ilokusi ekspresif dan 0 ilokusi deklaratif. Penyebab seringnya ilokusi asertif lebih sering muncul karena melibatkan pembicara pada kebenaran proposisi (mengutarakan, menyampaikan, menjelaskan, menerangkan, mengatakan), 
Arkhais, Vol. 07 SNo. 2 Jufi - Desember 2016

memberitahukan,menyarankan,membanggakan, mengeluh, menuntut, melaporkan. Penyebab tidak adanya ilokusi deklaratif dalam tuturan tersebut karena merupakan ilokusi yang bila perfomasinya berhasil akan menyebabkan korespondensi yang baik antara isi dengan realitas, seperti menyerahkan diri, memecat, membebaskan, membaptis, menamai, mengucilkan, mengangkat, menunjuk, menentukan, memvonis, dan lain sebagainya.

Berdasarkan kesimpulan hasil penelitian, saran yang dapat diberikan kepada mahasiswa yang berperan sebagi peneliti selanjutnya, diharapkan dapat memahamitindak tutur ilokusi pada percakapan yang terjadi di antara guru dan siswa.Selain itu, peneliti selanjutnya lebih mengerti keterbatasan siswa penyandang $D S$ dan suasana di Sekolah Luar Biasa.

\section{DAFTAR REFERENSI}

A Veskarisyanti, Galih. 2008. 12 Terapi Autis Paling Efektif dan Hemat. Yogyakarta: Pustaka Anggrek

Arifuddin. 2010. Neuropsikolinguistik. Jakarta: Rajagrafindo Persada

Chaer, Abdul. 2007. Linguistik Umum. Jakarta: Rineka Cipta

Dharma Yita dan Aillyard. 2000. TADIR: Tes Afasia untuk Diagnosis Informasi Rehabilitasi. Jakarta: Fakultas Kedokteran Universitas Indonesia

Geofrey, Leech. 1993. Prinsip-prinsip Pragmatik. Jakarta : Universitas Indonesia

Nadar, FX. 2009. Pragmatik dan Penelitian Pragmatik. Jakarta: Graha Ilmu

Parera, Jos Daniel. 1997. Linguistik Edukasional: Metodelogi Pembelajaran Bahasa Analisis Kontrastif Antarbahasa Analisis Kesalahan Bahasa. Jakarta: Erlangga

Purwo, Bambang Kaswanti. 2008. Pragmatik dan Pengajaran Bahasa, Yogyakarta: Kanisius

Rahardi, Kunjana. 2008. Pragmatik: Kesantunan Imperatif Bahasa Indonesia, Jakarta: Erlangga

S M, Lumbantobing. 2006. Anak dengan Mental Terbelakang, Jakarta: Universitas Indonesia

Parera, Jos Daniel. 1997. Linguistik Edukasional: Metodelogi Pembelajaran Bahasa Analisis Kontrastif Antarbahasa Analisis Kesalahan Bahasa Jakarta: Erlangga

Suyanto, Edi. 2011. Membina Memelihara dan Menggunakan Bahasa Indonesia Secara Benar. Yogyakarta: Ardana Media

Untung Yuwono Kushartanti, dan Multanis RMT Lauder. 2000. Pesona Bahasa: Langkah Awal Memahami Linguistik. Jakarta: PT. Gramedia Pustaka Utama

Verhaar J W M, Asas-asas Linguistik Umum. 2008 Yogyakarta: Gajah Mada University 